\title{
Fruit and Vitamin C Production of Five- and Six-Year-Old Acerola Trees
}

\author{
George C. Jackson and. William Pennock ${ }^{1}$
}

\section{INTRODUCTION AND OBJECTIVES}

The acerola (Malpighia punicifolia L.) is now a commercial crop in Puerto Rico and promises to increase in importance in the near future. There are established today over 400 acres of commercial plantings and one processing plant has been in operation for a number of years. New plantings continue to be established at an accelerated rate.

Aside from observations made by Moscoso $(5)^{2}$, Aróstegui, et al. (1), Aróstegui and Pennock (2), and Ledin (3, 4), there is very limited information with respect to probable yields from commercial plantings here in Puierto Rico or elsewhere in the world.

Our purpose has been to obtain reliable data on expected commercial yields as well as on comparative clonal performance.

\section{MATERIALS AND METHODS}

This study was carried out in a planting consisting of 163 trees which were set out in 1950. The planting comprised different selected clones in varying numbers, depending on their availability at the time of planting. The trees were set out at $16 \times 16$ foot spacing, and were fairly large plants derived from cuttings. They are now 6 to 10 feet tall with canopies 10 to 14 feet in diameter, depending on clonal growth habit. The trees may, therefore, be considered as having reached optimum or near-optimum size comensurate with the planting distance.

From now on some yearly pruning will necessarily have to be performed to facilitate mowing and other orchard-maintainance operations. To date pruning has been kept to a minimum and that done has been slight, mainly to improve tree shape during the first year after setting out. In subsequent years some small materials for propagation were cut from these trees. However, such branch-tip removal scarcely retarded their growth at all.

The recording of yields for each individual tree began in May 1955, at the start of the second cropping period for that year. It is unfortunate that the February crop for that year was past when this study was started. However, an estimate of this February crop has been made statistically. A

\footnotetext{
1 Research Assistant in Agronomy and Horticulturist, respectively, Agricultural Experiment Station, Unniversity of Puerto Rico, Río Piedras, P. R.

${ }^{2}$ Italic numbers in parentheses refer to Literature Cited, pp. 205.
} 
similar estimate was also made for the August crop in 1956. This latter crop was lost because of the hurricane of August 12.

Pickings were made at 2- and 3-day intervals. Whenever any dropped fruit was observed it was carefully picked up and included in the weighing. The fruit picked was either fully ripe or partially ripe, lacking an estimated 1, 2, or 3 days for complete ripeness. Doubtless commercial picking should be performed daily in order to get the fruit at its firm, almost ripe stage.

During the second year of this study samples consisting of 10 fruits were taken from the two highest yielding trees of each clone for vitamin $\mathrm{C}$ assay and for the determination of the refractive index of the juice. Samples were taken from each crop and were preserved by freezing for later determination. However, most of these samples were lost because of power failure following the hurricane of August 12. In consequence, only the samples of the October 1956 crop were actually properly assayed. For these assays the entire fruits were first osterized and then the determinations made from the filtered juice ${ }^{3}$.

\section{EXPERIMENTAL RESULTS}

Table 1 shows for 1955 and 1956, respectively, the 10 clones studied, the number of bearing trees of each clone in the planting, and the total yields per clone for each of the five crops during the year. Also shown are the annual clonal totals, the mean clonal yields per tree per year, and the mean clonal yield per tree per crop. A column of clonal totals from which the estimated crops have been excluded is also given.

In table 2 the yield data from both years are combined. To avoid tedious individual tree estimates, statistical analysis of clonal comparisons was performed using actual yields only ${ }^{4}$. In table 2, therefore, these actual yields are shown, as well as the yields which included estimates and which are therefore, more indicative of complete yearly performance.

In table 3 the clonal 2-year mean totals per tree are compared, and the statistically significant differences are shown. It will be seen therein that clone B15 outyielded all the other clones by a highly significant difference. In fact, it doubled or almost doubled the production of all the other clones except K7. It is unfortunate that there was only one tree of K7. Its yield data, therefore, lacked precision and were excluded from statistical comparison. Its indicated high yield in Puerto Rico must consequently be accepted with some reservations. This clone is the Florida Sweet which Ledin (5) has recently named and recommended for planting in Florida, where it is most vigorous and productive. It also grows vigorously in

3 These assays were performed by the Food Technology Laboratory of this Station.

${ }^{4}$ All statistical analyses were performed by the Statistical Section of this Station. 
TABLE 1.-Data on fresh acerola fruits harvested at the Isabela Substation clonal planting during 1955 and 1956 :

\begin{tabular}{|c|c|c|c|c|c|c|c|c|c|c|}
\hline \multirow[b]{2}{*}{$\begin{array}{l}\text { Year and } \\
\text { clones }\end{array}$} & \multirow[b]{2}{*}{$\begin{array}{l}\text { Trees } \\
\text { stud- } \\
\text { ied }\end{array}$} & \multicolumn{5}{|c|}{$\begin{array}{l}\text { Total fresh fruit harvested during different } \\
\text { cropping periods }\end{array}$} & \multirow[b]{2}{*}{$\begin{array}{c}\text { Clone } \\
\text { totals with } \\
\text { estimated } \\
\text { crops } \\
\text { excluded }\end{array}$} & \multicolumn{3}{|c|}{ Estimated crops included } \\
\hline & & $\begin{array}{c}\text { Febru- } \\
\text { ary }^{1}\end{array}$ & May & July & August $^{1}$ & October & & Total & $\begin{array}{c}\text { Mean } \\
\text { total } \\
\text { per tree }\end{array}$ & $\begin{array}{c}\text { Mean } \\
\text { per } \\
\text { tree } \\
\text { per } \\
\text { crop } \\
\text { har- } \\
\text { vest }\end{array}$ \\
\hline & $\begin{array}{c}N_{u l m-} \\
\text { ber }\end{array}$ & $L b$. & $L b$. & $L b$. & $L b$. & $L b$. & Lb. & $L b$. & $L b$. & $L b$. \\
\hline 1955 & & & & & & & & & & \\
\hline $\mathrm{A} 1$ & 57 & 301.4 & $1,201.4$ & $1,160.1$ & $1,451.2$ & $1,048.8$ & $4,861.5$ & $5,162.9$ & 90.6 & $\begin{array}{l}6 \\
6\end{array}$ \\
\hline B15 & 21 & 65.7 & 774.4 & $=938.6$ & 987.2 & $1,096.6$ & $3,796.8$ & $3,862.5$ & 183.9 & 36.8 \\
\hline B17 & 16 & 40.7 & 275.9 & 421.1 & 407.9 & 342.2 & $1,447.1$ & $1,487.8$ & 93.0 & 18.6 \\
\hline A2 & 16 & 104.4 & 346.8 & 252.9 & 364.1 & 163.2 & $1,127,0$ & $1,231.4$ & 77.0 & 15.4 \\
\hline A10 & 15 & 68.9 & 215.5 & 244.9 & 327.0 & 328.4 & $1,115.8$ & $1,184.7$ & 79.0 & 15.8 \\
\hline $\mathrm{A} 4$ & 11 & 23.4 & 322.7 & 137.9 & 395.2 & 144.3 & $1,000,1$ & $1,023.5$ & 93.0 & 18.6 \\
\hline A21 & 13 & 32.9 & 179.7 & 191.0 & 293.1 & 280.9 & 944.7 & 977.6 & 75.2 & 15.0 \\
\hline B9 & 7 & 9.1 & 116.3 & 146.4 & 174.0 & 142.4 & 579.1 & 588.2 & 84.0 & 16.8 \\
\hline B2 & 6 & 20.0 & 202.3 & 90.0 & 196.0 & 50.1 & 538.4 & 558.4 & 93.1 & 18.6 \\
\hline K7 & 1 & 11.3 & 33.6 & 44.7 & 37.1 & 27.1 & 142.5 & 153.8 & 153.8 & \begin{tabular}{l|l}
30.8 \\
30.8
\end{tabular} \\
\hline Total & 163 & 677.8 & $3,668.6$ & $3,627.6$ & $4,632.8$ & $3,624.0$ & $15,553.0$ & $16,230.8$ & $1,022.6$ & 204.5 \\
\hline $\begin{array}{l}\text { Mean per } \\
\text { tree }\end{array}$ & 1 & 4.2 & 22.5 & 22.3 & 28.4 & 22.2 & & 99.6 & 102.3 & 19.9 \\
\hline 1956 & & & & & & . & & & & \\
\hline A1 & 57 & 412.0 & $2,127.8$ & $1,971.5$ & $1,984.0$ & $1,206.2$ & $5,717.5$ & $7,701.5$ & 135.1 & 27.0 \\
\hline B15 & 21 & 89.8 & $1,298.9$ & $1,129.8$ & $1,349.6$ & $1,267.7$ & $3,786.2$ & $5,135.8$ & $\begin{array}{l}344.6\end{array}$ & 48.9 \\
\hline B17 & 16 & 55.7 & 408.5 & 207.6 & 557.6 & 271.2 & 943.0 & $1,500.6$ & 93.8 & \begin{tabular}{l|l}
38.8 \\
18
\end{tabular} \\
\hline A2 & 16 & 142.8 & 767.3 & 543.9 & 497.8 & 542.4 & $1,996.4$ & $2,494.2$ & 155.9 & 31.2 \\
\hline A10 & 15 & 94.2 & 294.1 & 176.1 & 447.0 & 203.0 & 767.4 & $1,214.4$ & 80.9 & 16.2 \\
\hline $\mathrm{A} 4$ & 11 & 32.0 & 482.2 & 175.1 & 540.3 & 90.0 & 779.3 & $1,319.6$ & 120.0 & 24.0 \\
\hline $\mathrm{A} 21$ & 13 & 45.0 & 379.1 & 165.2 & 400.7 & 240.3 & 829.6 & $1,230.3$ & 94.6 & 18.9 \\
\hline B9 & 7 & 12.5 & 176.7 & 66.1 & 237.9 & 157.9 & 413.2 & 651.1 & 93.0 & 18.6 \\
\hline $\mathrm{B} 2$ & 6 & 27.3 & 267.5 & 114.3 & $\quad 268.0$ & 122.8 & 531.9 & 799.9 & ) 133.3 & 26.7 \\
\hline K7 & 1 & 15.4 & 35.7 & 30.5 & 50.7 & 9.8 & 91.4 & 142.1 & l) 142.1 & 28.4 \\
\hline Total & 163 & 926.7 & $6,237.8$ & $4,580.1$ & $6,333.6$ & $4,111.3$ & $15,855.9$ & $22,189.5$ & $1,293.3$ & 258.7 \\
\hline $\begin{array}{l}\text { Mean per } \\
\text { tree }\end{array}$ & 1 & 5.7 & 38.3 & 28.1 & 38.8 & 25.2 & & 136.1 & 129.3 & 27.2 \\
\hline
\end{tabular}

${ }^{1}$ Estimated statistically for August 1956. 
Puerto Rico and quite probably is a higher yielder than many of our selections. It will also be observed in table 3 that clone A2 was a significantly higher yielder than $\mathrm{A} 21$ and $\mathrm{A} 10$, and that clone $\mathrm{A} 1$ also gave a significantly higher yield than A21 or A10. Clone B17, which has heretofore been regarded as our best clone, was actually outyielded by four of the clones in the experiment, but only B15 outyielded it significantly.

Table 4 gives the vitamin $\mathrm{C}$ determinations expressed as grams per $100 \mathrm{gm}$. of fresh fruit. These data are not significant at the 5-percent level. Table 5 is a summary of analyses of variance. As may be seen, the F

TABLE 2.-Combined acerola yield data from clonal planting at the Isabela Substation for 1955 and 1956

\begin{tabular}{|c|c|c|c|c|c|c|c|c|}
\hline \multirow[b]{2}{*}{ Clones } & \multirow[b]{2}{*}{$\begin{array}{c}\text { Trees } \\
\text { studied }\end{array}$} & \multicolumn{4}{|c|}{ Data excluding estimates } & \multicolumn{3}{|c|}{ Data including estimates } \\
\hline & & $\begin{array}{c}\text { Totals } \\
\text { from table } 1\end{array}$ & $\begin{array}{c}\text { Harvested } \\
\text { August 9, } \\
1956^{1}\end{array}$ & 2-year total & $\begin{array}{c}\text { Mean 2- } \\
\text { year total } \\
\text { per tree }\end{array}$ & $\begin{array}{c}\text { 2-year } \\
\text { total }\end{array}$ & $\left|\begin{array}{c}\text { Mean 2- } \\
\text { year total } \\
\text { per tree }\end{array}\right|$ & $\begin{array}{l}\text { Mean per } \\
\text { year per } \\
\text { tree }\end{array}$ \\
\hline & Number & $L b$. & $L b$. & $L b$. & $L b$. & $L b$. & $L b$. & $L b$. \\
\hline B15 & 21 & $7,583.0$ & 48.8 & $7,631.8$ & 363.4 & $8,998.3$ & 428.5 & 214.3 \\
\hline $\mathrm{A} 2$ & 16 & $3,123.4$ & 23.1 & $3,146.5$ & 196.7 & $3,725.6$ & 232.9 & 116.5 \\
\hline $\mathrm{A} 1$ & 57 & $10,579.0$ & 215.6 & $10,794.6$ & 189.4 & $12,864.4$ & 225.7 & 112.9 \\
\hline $\mathrm{B} 2$ & 6 & $1,070.3$ & 2.7 & $1,073.0$ & 178.8 & $1,358.3$ & 226.4 & 113.2 \\
\hline A4 & 11 & $1,779.4$ & 0 . & $1,779.2$ & 161.7 & $2,343.1$ & 213.0 & 106.5 \\
\hline B17 & 16 & $2,390.1$ & 19.5 & $2,409.6$ & 150.6 & $2,988.4$ & 186.8 & 93.4 \\
\hline B9 & 7 & 992.3 & 5.3 & 997.6 & 142.5 & $1,239.3$ & 177.0 & 88.5 \\
\hline A21 & 13 & $1,774.3$ & 7.7 & $1,782.0$ & 137.1 & $2,207.9$ & 169.8 & 84.9 \\
\hline A10 & 15 & $1,883.2$ & 4.5 & $1,887.7$ & 125.8 & $2,399.1$ & 159.9 & 80.0 \\
\hline $\mathrm{K} 7$ & 1 & 233.9 & 0 & 233.9 & 233.9 & 295.9 & 295.9 & 148.0 \\
\hline
\end{tabular}

${ }^{1}$ Only 1 harvest was made in August 1956, which was followed by the hurricane of Aug. 12, 1956. These data excluded from table 1 are shown here to explain mean clonal totals later used for statistical comparisons.

value of 2.61 is just short of the required value for 5-percent level of significance which is 2.85 . Though just short of the usually accepted standard of significance, the data are not entirely untrustworthy. Since the data are the only available index of clonal vitamin $\mathrm{C}$ content, we have used them in estimating the annual production of vitamin $\mathrm{C}$ per tree as is shown in table 6. As may be seen therein, clone B15 exceeded all the other clones in vitamin $\mathrm{C}$ production. Clone B17, on the other hand, appears to produce less vitamin $\mathrm{C}$ than most of the other clones except A10.

\section{DISCUSSION}

As may be seen in table 1, five well-defined bearing periods occurred during 1955 and 1956 . Since the acerola has only recently become a commer- 


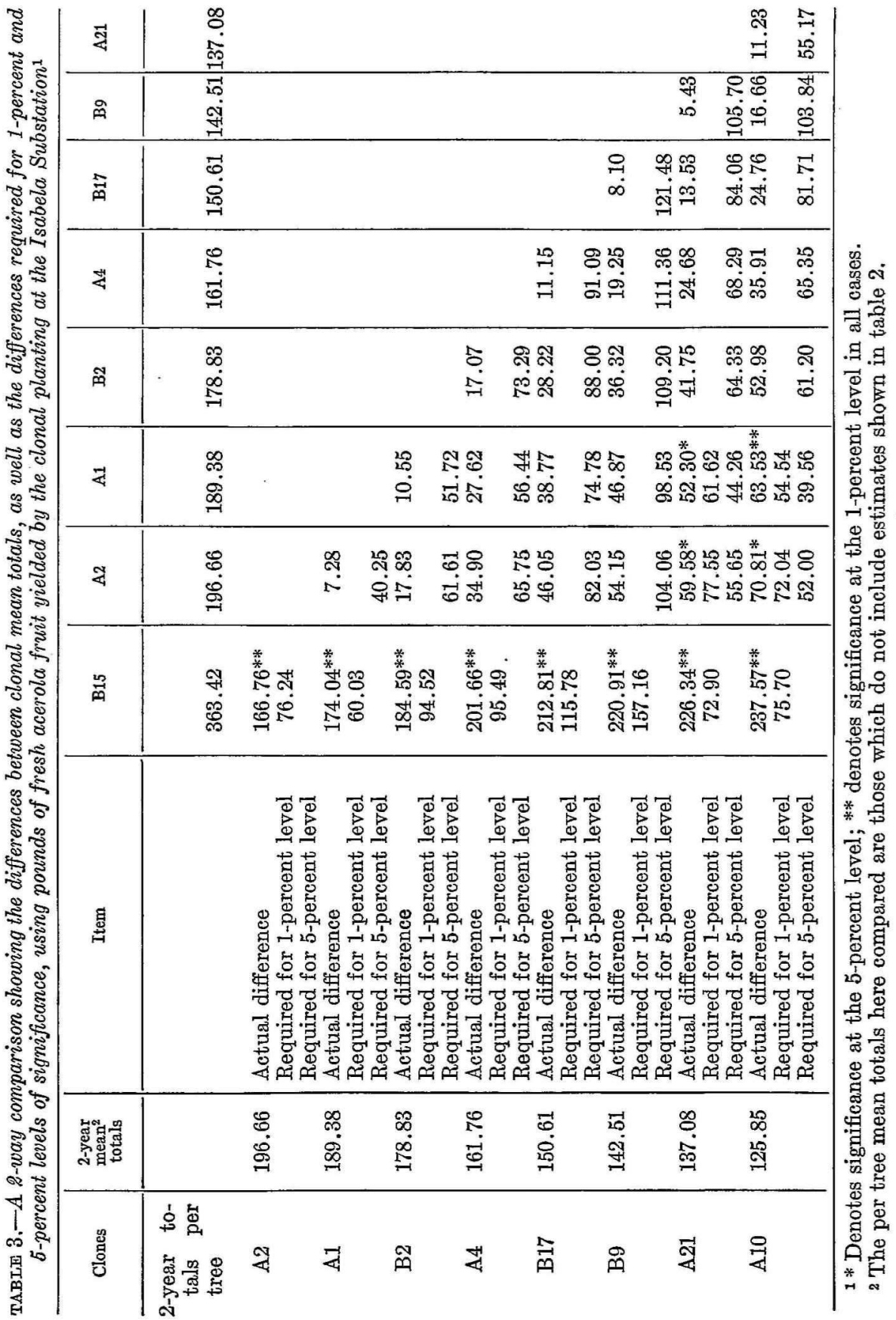


TABLE 4.-The vitamin $C$ content of acerola-fruit samples taken October 1956 from some of the highest yielding trees of each clone at Isabela Substation clonal planting, expressed as grams per $100 \mathrm{gm}$. of fresh fruit

\begin{tabular}{l|c|c|c|c|c|c|c|c|c|c|c}
\hline \multirow{2}{*}{$\begin{array}{c}\text { Tree } \\
\text { sampled }\end{array}$} & \multicolumn{6}{|c|}{ Vitamin C content (grams) per 100 gm. fresh fruit for the different clones } & Totals \\
\cline { 2 - 9 } & B17 & B15 & A2 & B2 & A1 & A4 & B9 & A21 & A10 & K7 & \\
\hline 1st & 1.97 & 2.12 & 2.71 & 2.13 & 2.22 & 1.63 & 2.18 & 2.25 & 2.50 & 1.79 & 21.50 \\
2nd & 2.03 & 2.36 & 2.49 & 1.65 & 1.95 & 1.52 & 2.68 & 2.75 & 1.81 & - & 19.24 \\
3d & 1.93 & 2.36 & - & - & - & - & - & - & - & - & 4.29 \\
4 th & 1.90 & - & - & - & - & - & - & - & - & - & 1.90 \\
Total & 7.83 & 6.84 & 5.20 & 3.78 & 4.17 & 3.15 & 4.86 & 5.00 & 4.31 & 1.79 & 46.93 \\
Means & 1.96 & 2.28 & 2.60 & 1.89 & 2.09 & 1.58 & 2.43 & 2.50 & 2.16 & 1.79 & 2.13 \\
\hline
\end{tabular}

TABLE 5.-Summary of analyses of variance performed on data pertaining to vitamin

$C$ content of fruit from acerola trees in the Isabela Substation clonal planting

\begin{tabular}{l|r|r|r|c}
\hline \multicolumn{1}{c|}{ Source } & D.F. & Stms of squares & Variance & F value \\
\hline Total & 21 & $\begin{array}{r}2.6519 \\
1.7542 \\
.8977\end{array}$ & $\begin{array}{r}0.1949 \\
.0748\end{array}$ & 2.61 \\
Between clones & 12 & & \\
Within clones & 12 & 2.85 \\
\hline \multicolumn{2}{c}{ Value at the 5-percent level of significance } & & \\
\hline
\end{tabular}

TABLE 6.-The mean annual yield of acerola fruit per tree, the vitamin $C$ content of the fresh fruit, and the estimated total yield of vitamin $C$ per tree for clonal planting at Isabela Substation

\begin{tabular}{l|c|c|c|c}
\hline Clone & Trees & $\begin{array}{c}\text { Annual fruit yield } \\
\text { per tree }\end{array}$ & $\begin{array}{c}\text { Content of vitamin } \\
\text { C based on fruit } \\
\text { weight }\end{array}$ & $\begin{array}{c}\text { Annual production } \\
\text { of vitamin C } \\
\text { per tree }\end{array}$ \\
\hline & Number & Lb. & Per cent & $L b$. \\
B15 & 21 & 214 & 2.28 & 4.88 \\
A2 & 16 & 116 & 2.60 & 3.02 \\
K7 & 1 & 148 & 1.79 & 2.65 \\
A1 & 57 & 113 & 2.09 & 2.36 \\
B9 & 7 & 89 & 2.43 & 2.16 \\
B2 & 6 & 113 & 1.89 & 2.14 \\
A21 & 13 & 85 & 2.50 & 2.13 \\
B17 & 16 & 93 & 1.96 & 1.82 \\
A10 & 15 & 80 & 2.16 & 1.73 \\
A4 & 11 & 107 & 1.58 & 1.69 \\
Weighted means & & 118 & 2.17 & 2.56 \\
\hline
\end{tabular}


cial crop and its bearing habits have not been carefully observed and reported, we have considered it desirable to examine the data with the view of generalizing regarding the periodicity of fruiting throughout the year.

Table 7 shows the bearing and nonbearing periods for 1955 and 1956, giving the dates as well as the number of days included in each period. As can be seen in table 7 the data pertaining to duration of the resting peri-

TABLE 7.-The bearing and nonbearing periods (days) of acerolas at the Isabela clonal planting during 1955 and $1956^{1}$

\begin{tabular}{|c|c|c|c|c|c|}
\hline \multicolumn{3}{|c|}{1955} & \multicolumn{3}{|c|}{1956} \\
\hline $\begin{array}{l}\text { Resting } \\
\text { periods }\end{array}$ & $\begin{array}{l}\text { Bearing } \\
\text { periods }\end{array}$ & Dates (inclusive) & $\begin{array}{l}\text { Resting } \\
\text { periods }\end{array}$ & $\begin{array}{l}\text { Bearing } \\
\text { periods }\end{array}$ & Dates (inclusive) \\
\hline Days & Days & & Days & Days & \\
\hline 113 & & Nov. 1-Feb. 21 & 110 & & Nov. 1-Feb. 18 \\
\hline & 7 & Feb. 22-Feb. $28^{2}$ & & 6 & Feb. 19-Feb. 24 \\
\hline 79 & & Mar. 1-May 18 & 65 & & Feb. 25-Apr. 29 \\
\hline & 20 & May $19-J u n e ~ 7$ & & 17 & Apr. 30-May 16 \\
\hline 27 & & June 8-July 4 & 33 & & May 17-June 18 \\
\hline & 18 & July 5-July 22 & & 15 & June 19-July 3 \\
\hline 32 & & July 23 -Aug. 23 & 36 & & July 4-Aug. 8 \\
\hline & 24 & Aug. 24-Sept. 16 & & 22 & Aug. 9-Aug. $30^{3}$ \\
\hline 16 & & Sept. 17-Oct. 2 & 26 & & Aug. 31-Sept. 25 \\
\hline & 29 & Oct. 3-Oct. 31 & $8^{4}$ & 28 & $\begin{array}{l}\text { Sept. } 26 \text {-Oct. } 23 \\
\text { Oct. } 24 \text {-Oct. } 31\end{array}$ \\
\hline $267^{5}$ & $98^{5}$ & & $278^{5}$ & $88^{5}$ & 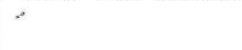 \\
\hline
\end{tabular}

1 The years are shown as starting on November 1, 1954 and 1955, presumably the first day of the resting period following the last harvest of the previous year.

${ }^{2}$ This period was not actually recorded. The length of the period in days was estimated statistically and the dates set down as could best be recalled from memory. It is substantially correct, plus or minus a few days.

${ }^{3}$ Aug. 9 was the date of the first and only picking made during this bearing period. The hurricane of Aug. 12 destroyed the remainder of the crop. The length of this cropping period was estimated statistically.

${ }^{4}$ Period to complete year on Oct. $31,1956$.

5 Totals.

ods on the one hand, and to the duration of the bearing periods on the other, appear to follow a well-defined seasonal pattern which is similar for both years. The length of the resting period started at about 112 days, decreased rapidly at first to about 70 days and then tapered off by gradually decreasing differences to a length of about 21 days. These data suggest a parabolic decrease in the length of the resting period for the year starting on November 1 . The bearing periods, on the other hand, started at about 7 days duration and increased roughly linearly to a duration of 
about 28 days. However, since in both cases we are dealing with a recurring yearly phenomenon, an S-type curve would be required to fit the data applying to a period slightly longer than a year. The linear increase in the length of the bearing period should be regarded as the central section of a rather flat S curve.

Despite the suggested curves, however, the data are obviously too skimpy to provide the best fitting curves with acceptable standards of precision. Pending possible future corroboration, the information available at present on the pattern of production is as follows:

1. At the Isabela Substation in Puerto Rico, 10 selected clones of acerola produced in five well-defined cropping periods during the year 1955 and again in 1956. These cropping periods lasted from 1 to 4 weeks, during which successive fruit production was roughly continuous on a day-to-day basis for most trees. During the longest periods ripe fruit and bloom were frequently observed on the trees coincidentally.

2 . In both years the four longest and most productive periods, accounting for 96 percent of the fruit, occurred during the months of May to October, inclusive. This coincides with relatively warm weather and abundant rainfall. If we allow a time lag of about 4 weeks for flower initiation, plus the known interval of 3 weeks from open flower to ripe fruit, it appears to coincide also with bloom induction which occurred after the spring equinox and before the autumm equinox. Fruit production during these months, therefore, corresponds to bloom induction during day-lengths of 12 to 13 hours.

3. A short bearing period lasting 1 week occurred in February of both years, when production amounted to only 4 percent of the yearly total. February is a relatively cold dry month in Puerto Rico and its corresponding bloom-induction period took place during the shortest days of the year having a few minutes more than 11 hours of daylight.

It would appear, therefore, that day length, within the Puerto Rican limits of variation, does not exert a clear-cut influence on bloom induction in acerolas. It may well be that a completely nonproductive winter may occur at a more northerly latitude. We believe such is the case in Dade County, Fla., where day-lengths in winter are reduced to as low as $10 \frac{1}{2}$ hours. However, this could be attributable to factors other than length of day.

4. Despite the recurrence of five general bearing periods during each of the two years of this study, there were some individual trees which only had four such periods, and a few were observed to have a few fruit in December 1956. These fruits were not harvested because so few, but they suggest the possibility that six bearing periods per year may occur in some instances. Such erratic behavior with respect to periodicity of bloom was observed to be much more frequent in an adjacent seedling planting which 
was harvested during these same years, but for which no records were kept. It seems probable, therefore, that some clones may be found with a tendency to bloom more frequently during the year than others. Our present selections did not show much difference in this respect.

As regards probable yields from commercial production, the weighted mean obtained for all clones over the two years is doubtless our best estimate. As shown in table 6, it amounted to 118 pounds of fruit with a vitamin $\mathrm{C}$ content of 2.17 percent, or an estimated per tree per year yield of 2.56 pounds of vitamin C. However, it must be remembered that most of the clones included in this study were originally selected because of high content of vitamin $\mathrm{C}$, and that their average is probably higher than the content of fruit in most commercial plantings. We believe, therefore, that 2 percent is a better estimate of vitamin $\mathrm{C}$ content of the fruit for commercial plantings in Puerto Rico.

On a per acre basis then, at $16 \times 16$-foot spacing, there would be 170 trees per acre, which would yield roughly 10 tons of fruit containing approximately 400 pounds of vitamin C. Because of the large size of these trees, and the need of holding them to present size by pruning, future yields of this planting will increase but slightly if at all. At wider spacing doubtless the trees could be allowed to attain a larger size, and would yield more individually, but there would be fewer trees per acre in rough compensation. These estimates, therefore, may be regarded as applying to an orchard in full production.

Regarding clonal superiority for commercial purposes: The data herein presented show beyond reasonable doubt that clone B15, under the conditions of this experiment, greatly outyielded all the others in terms of both fresh fruit and vitamin C. Since these conditions are presumably similar in their important essentials to those where acerolas are gown commercially on the Island, we strongly recommend clone B15 for commercial planting in Puerto Rico. Barring some possible undiscovered regional factor which might adversely affect its relative performance, the use of this clone would be expected to more than double the above estimated yields. The Florida Sweet (K7) is undoubtedly an outstanding clone for home planting and consumption as fresh fruit.

\section{SUMMARY}

1. The production records obtained from 163 individual acerola trees belonging to 10 selected clones at the Isabela Substation are shown for the years 1955 and 1956. The trees were 5 and 6 years old from time of setting out as large, well-rooted cuttings.

2. The trees bore fruit during five well-defined cropping periods, which consisted of from 1 to 4 weeks of continuous production. These bearing 
periods were interspersed with resting periods which varied from 2 to 16 wreeks.

3. The four longest bearing periods, accounting for 96 percent of the yearly fruit total, occurred during the months of May to October, inclusive.

4. The yearly yield per acre of a commercial planting in Puerto Rico is estimated at 10 tons of fruit containing 435 pounds of vitamin $\mathrm{C}$.

5. The most productive clone, now strongly recommended for commercial plantings, was B15 which more than doubled the above estimates. The Florida Sweet (K7), a selection made at Homestead, Fla., gave a high yield of fruit which had a relatively low vitamin content. It is rated as an outstanding clone for consumption as fresh fruit.

\section{RESUMEN}

1. Se presentan en este trabajo datos sobre la producción anual de 163 árboles seleccionados de 10 variedades de acerola. Estos árboles fueron propagados asexualmente y sembrados en la Subestación de Isabela. Tenían 5 y 6 años de edad al ser cosechados en 1955 y 1956.

2. En ambòs años la fruta se recogió durante 5 distintas épocas de cosecha cuya duración fué de una a cuatro semanas de producción continua. Entre cosechas hubo intervalos de descanso que duraron de 2 a 16 semanas.

3. Las cuatro cosechas mayores, cuyo total corresponde al 96 porciento de toda la fruta cosechada durante el año completo, ocurrieron durante los meses de mayo a octubre, inclusive.

4. El rendimiento anual para siembras comerciales en Puerto Rico se calcula en 10 toneladas de fruta por cuerda con un contenido de 400 libras de vitamina $\mathrm{C}$.

5. La variedad clonal de mayor rendimiento fué la B15, la cual superó a todas las otras por un margen altamente significativo. De sembrarse esta variedad podrían doblarse los rendimientos arriba indicados. La variedad Florida Sweet (K7) dió un alto rendimiento de fruta fresca con un contenido relativamente bajo de vitamina $\mathrm{C}$.

\section{LITERATURE CITED}

1. Aróstegui, F., Asenjo, C. F., Muñiz, A. I., and Alemañy, L., Observations and data on a promising selection of the West Indian cherry, Malpighia punicifolia L., J. Agr. Univ. P. R. 39 (2) 1-51, 1955.

2. Aróstegui, F., and Pennock, W., The acerola, Misc. Pub. No. 15, Agr. Exp. Station, Univ. P. R., Río Piedras, P. R., May 1956.

3. Ledin, R. B., The West Indian or Barbados Cherry, mimeographed report, Homestead Exp. Sta., Univ. Fla., pp. 2, Aug. 1955.

4. - A comparison of three clones of Barbados eberry and the importance of improved selections for commercial plantings, Proc. Fla. Sta. Hort. Soc., 69 293-7, Nov. 1956.

5. Moscoso, C., West Indian cherry-Richest known source of natural vitamin C., Econ. Bot. 10 (3) 280-94, July-Sept. 1956. 